\title{
Increasing Intensive Study by Using Combination Model of The Cooperative Integrated Reading and Composition (CIRC), Team Assisted Individualization (TAI), and Numbered Head Together (NHT)
}

Ramadi, Noviyanti, Azizah*,

Graduate Program of Elementary Education, Universitas Negeri Malang, Malang, Indonesia.

\begin{tabular}{|c|c|}
\hline ARTICLE INFO & A B STRACT \\
\hline \multirow[t]{2}{*}{$\begin{array}{l}\text { Received: I8-I0-20I8 } \\
\text { Revised: 08-I I-20I8 } \\
\text { Accepted: 07-I2-20I8 } \\
\text { Keywords: } \\
\text { Cooperative, Integrated } \\
\text { Reading and Composition, } \\
\text { Team Assisted } \\
\text { Individualization and } \\
\text { Numbered Head Together. }\end{array}$} & $\begin{array}{l}\text { The purpose of this study is to determine the activities of the teacher, student } \\
\text { activities and student learning outcomes read intensive through the combination of } \\
\text { learning models Cooperative Integrated Reading and Composition (CIRC), Team } \\
\text { Assisted Individualization (TAI) and the Numbered Head Together (NHT). This } \\
\text { research is using class behavior research which is done in } 2 \text { cycles. Research setting } \\
\text { is in the SDN Pengambangan } 9 \text { East Banjarmasin school year 20I6/20I7 } 2 \mathrm{nd} \\
\text { semester in grade IV. The results showed that there is an increase in each cycle. It } \\
\text { can be seen from the teacher's activity in the cycle that earned the score } 33 \text { with } \\
\text { category "Good" and in cycle II that earned score } 42 \text { with the category "Very } \\
\text { Good". The student's activity in the learning process in cycle I am classically } 46 \% \\
\text { with the category of "Quite Active" and in cycle II is classically } 75 \% \text { with category } \\
\text { "Active". Meanwhile, the student's learning result classically in cycle I reaches } 81 \% \\
\text { and it increases to } 92 \% \text { in cycle II. }\end{array}$ \\
\hline & $\begin{array}{l}\text { (c) } 2018 \text { The Authors. Journal of K6, Education, and Management (j-K6EM). ISSN: } 2580-2135 \text {. } \\
\text { Published by Graduated Program of Educational Management, Universitas Lambung } \\
\text { Mangkurat, Banjarmasin, Indonesia. This is an open access article under the open journal } \\
\text { systems. }\end{array}$ \\
\hline
\end{tabular}

*Author correspondence: Azizah; E-mail: Azizahpgsd01@gmail.com 


\section{Introduction}

Today's globalization era has been impacted to the rising of the global rivalry between each country of the world. The excellent of the society is very important for the developing country because the development of the country depends on the quality of the human resources itself, and education is the best way to produce an excellent society as well. Increasing the quality of the human resources through education is the main priority of the educational world. Education is one of the highest need's development structure of the countries. Therefore, it is such an irreplaceable element of them.

Education can be meant as a trial process from an adult people who have already had their awareness to lead, coach, teach and plant the views of life to the young generation. So they could be responsible to their life as a person which is appropriate with the characteristic of human beings as well. According to John Dewey education is a fundamental basic skill establishing the process which is relating to the intellectual and emotional concept of human.

The constitution of the national world education in section I verse I has been mentioned that "In the learning process of education, the first impression that will be caught of the student (student refers to goals because the student who has the goal itself) is how the condition and the ability of them before determining other components. The material will be needed, the suitable action will be taken and the facilities will be supported have to be adapted according to the characteristics of the student. That's why the students are the subjects of the education itself (Sardiman, 20II).

Suriansyah (20II) mention "the goal of the education in many countries has many differences according to their own view of life" as same as the purpose of the life of Indonesia as a developing country will be so much different with many another developed country as well.

It is corresponding to the opening of Undang Undang Dasar Negara Republik Indonesia 1945 which is mentioned "the Indonesia Government that protect all the Indonesian people and the whole Indonesia and for advancing the public welfare, educating the life of the nation, and participating in the world order based on the freedom, eternal peace and social justice).

Concerning about the quality of the school and human resources is the main structure of creating the high quality of education as well. In the other words, it has to be needed an effort to increase the quality of the education that will always do anytime, anywhere and any situation.

The innovation of the curriculum structure, an effective and efficient educational system and learning method are the consequence of the developing education world nowadays. Increasing the infrastructure, the quality of the teachers and students also the improvements of the curriculum can be a held as optional efforts (Rusman, 2010).

Education is the key of the successful and improvements of the country. Therefore the governments will always make serious efforts to increase the quality of the education of the country by updating the educational curriculum continuously. Bruner mention that learning process does not change the educational curriculum as of the student will study much more subjects and easier for learning new skills and any other knowledge (Daryanto, 2010).

Education is being one of the changing efforts to create a very well planned atmosphere, as a delving own self-potential effort and producing the new better goal of life. It is corresponding to the Undang Undang Republik Indonesia number 20 years 2003 about National Educational System:

"Education is the conscious and well-planned effort to create an atmosphere of learning and learning process so that learners actively develop their potential to have religious spiritual power, selfcontrol, personality, intelligence, noble character, as well as the skills needed by themselves, society, nation and state" (Chapter I ArticleI).

Education is the most precious treasure of life as a function of an investment and principal asset of a country as well.

The function and purpose of the national education revers to Undang Undang Republik Indonesia number 20 years 2003 about national educational system is:

"National education function is to develop the ability and form the character and civilization of 
dignified nation in order to educate the life of the nation, aims to develop the potential of learners to become human beings who believe and piety to God Almighty, noble, healthy, knowledgeable, capable, creative, independent and become a democratic and responsible citizen " (Chapter 2 of Article 3).

The learning process is an interaction process between the student and the teacher and also the source of the study in the learning environment (UU SISDIKNAS Bab I: Pasal I). For creating that learning process atmosphere, there are some proponent materials required in order to make it more efficient and fun.

On the situation of that learning process, the teacher should pay their attention to the point from the Undang Undang Number I9 2005 which is mentioned:

"The pursuit of educational units is organized in an interactive, inspiring, fun, challenging, motivational way for active participation, and provides sufficient space for initiative, creativity, and independence according to the students' physical and psychological talents, interests and development" (Chapter IV Article I9).

According to the UU Sisdiknas No 202003 paragraph 37 verse I mention "The elementary school curriculum should consist of: Religion objects, Civics, Bahasa Indonesia, Mathematics, Social Sciences, Dance and Culture, Sports, Vocational Skills and Local Contents". It shows how the Bahasa Indonesia cannot be skipped from the phase of the elementary school because it teaches the skills of speaking and writing as well.

According to Panduan Kurikulum Satuan Pendidikan (KTSP) SD/MI (2006) or the Educational Curriculum of Elementary school, the purpose of subjects Bahasa in the elementary school are as follows:

I. It has an ability to communicate effectively and efficiently revers to the norm applies to neither speaking nor writing.

2. Respect and proud to use Bahasa as their national language.

3. Understand Bahasa and use it correctly and creatively for many purposes.

4. Using Bahasa to elevate intellectual skill, emotional and social maturity.
5. Enjoy and utilize literature work to beautify character and elevating the knowledge and skill of language.

6. Respect and proud of literary works of Indonesia as a cultural treasure and human intellectual of Indonesia.

There are 4 aspects which is including learning process of Bahasa. They are listening, speaking, reading and writing. With all of those competencies, a student can be effectively communicated in any requirements. The skill of language consists of writing and speaking skill. The skill of writing consists of reading and writing skills while speaking skill consists of listening and speaking skills.

To achieve the purpose of the national education, basic knowledge that applies on the elementary school through Bahasa needs to be taught because the ability of the student in understanding many other subjects is depending on the quality of the basic knowledge itself.

According to the fact through the research and interview which is held on November, I2th 2016 to Mrs. Nurhidayah, S.Pd the teacher of IV grade SDN Pengambangan 9 Banjarmasin Timur shows that the intensively reading ability of the students of fourth grade of SDN Pangambangan 9 Banjarmasin Timur (Panganbangan 9 Banjarmasin Timur Elementary school) to determine the main sentence, main idea and summary of the contents have not complete to the expectations yet.

According to the first observation result in SDN Pengambangan 9 Banjarmasin Timur on the subjects Bahas, the material of intensively reading could be seen from formative value on the first semester of 2015/2016, only 13 out of 37 students or just $35,1 \%$ of the students who has been completing the KKM, meanwhile there are 24 students or $64,9 \%$ who has not been completing yet the minimum passing value criteria on 70 . It is because of the passive response of the students in consequence of using one way of learning method that makes the students also losing their interest and motivation of study. It caused the students have difficulty to understand the reading concept and ideas very well so they have been stuck in solving the assignments and they also got less of confidence and creativities to be on presentation.

On the learning process of SDN Pengambangan 9 Banjarmasin Timur, the students rate the intensively reading is being one of the most difficult to understand the materials. Meanwhile, the students should be easier to find the main sentence, main 
idea and summary of the content by only listening to 500 sentences in 2 minutes properly. But they can't. They do not recognize the meaning of the sentences, they do not know the important phenomenon in the society even in the world, they do not know how to measure the idea of the writer and find out the values of the contents. They are just sitting around in the class. The domination of the teacher in the learning process by lecturing method caused the students do not get any learning experience as supposed to do. It also makes them just receiving the concept and bored with the situation, lack of passion and creativity. It caused to the lack of their activity and their scores as well.

In the subject of Bahasa, some students are having difficulties to understand the content. Many of them are difficult to determine the main idea of the content in the paragraph. They also having difficulties to summarize the material because of the explanation of the teacher is not clear enough. Tarigan (2009) declare: "Intensive reading requires essentially a text of no more than 500 words (which can be read in a 2 -minute period at a rate of about 5 words in a second). The ultimate goal is to succeed in full understanding of the logical arguments, theoretical sequences, the symbolic patterns).

The skill which is asked in the intensively reading for every grade especially in the fourth grades is, to complete the purpose of the study which follows: understand the meaning of the contents in a basic educational degree and the speed ability of the reading to read 3 words in a second.

The intensive reading which is a component of the subject of Bahasa has to be taught by the teacher in practicing method. However, choosing the right and fun method by using the suitable media in order to facilitate the learning process is being the same obstacle for neither the teacher nor the student.

Bahasa Indonesia as a subject with intensively reading becomes the major point of the discussion should be taught in practicing method for the student by the teacher. However, both of the teacher and the student feel the same obstacle as their problem as well. It is about which one the best and fun method of the learning process and what media they could be adopted in order to make the learning process will be so much easier to be understood for the student especially the intensively reading concept.

According to the problems, the right media and system of the learning process have to be completed as they involving the student to be more active so that will be increasing the desire and willingness study of the student especially the subject of Bahasa Indonesia. And using some media and the combination of the learning process will be the best way. To make the learning process of Bahasa Indonesia becoming a creative, productive, cooperative and collaborative one, it has to be developed by creating something that stimulates the activity and creativity of the student and makes them capable to find their expression and discuss with the other to solve any problems. One of the combination learning process method which is involving the student straightforward to the process is a cooperative learning type Cooperative Integrated, Reading and Composition (CIRC) Team Assisted Individualization (TAI) and Numbered Head Together (NHT) because its method concern to the learning process in a group but is not doing something together only. The learning process which is held in a group will help the student find out and build their comprehension by themselves about the subject. Something that cannot be found in the conventional learning process (Nur, 2010)

An appropriate cooperative learning process for the subject of Bahasa Indonesia in intensively reading of some contents is a combination cooperative learning process method Cooperative Integrated, Reading and Composition (CIRC), Team Assisted Individualization (TAI) and Numbered Head Together (NHT).

Steven and Slavin (I995) mention that Cooperative Integrated Reading and Composition (CIRC) is a comprehensive prototype for the instruction of the reading and writing the aspect to the elementary school students. Cooperative Integrated Reading and Composition (CIRC) consider as the most important to the group of the student's ability. (Fakhrudin, 20I I)

Team Assisted Individualization (TAI) has the main idea which is adapting the learning process to the individual differences relate to the performance of the student. This method includes the cooperative learning process. In this method, the student could be set in a small group consist of 4 or 5 heterogeneous persons which is followed by giving an individual help to the one who needs it. By group learning method, hopefully, the students can increase their critical idea, creativity and high social feelings of them (Suyitno, 2007).

Numbered Head Together (NHT) is one of the cooperative learning process strategies. This 
learning process method was developed by Spenser Kagan (1993) in Nurhadi and Agus (2003). It refers to the student's group of study which each member has their own assignments with different of the number.

If those three methods have been combined, Cooperative Integrated Reading and Composition (CIRC), Team Assisted Individualization (TAI) and Numbered Head Together (NHT), we can create a very good activity in the learning process as the benefits. Because the combination of the methods makes the student can read, discuss and help each other together but they still have to take the responsibility to present the result of their discussion by themselves. So there is nothing passive student because they have to participate in the discussion.

\section{Methodology}

Method of the approach of the study is the qualitative method. The qualitative method is used by the writer to fix the quality of the learning process and the performance of the writer as a teacher. And the type of the study is class action research.

According to Aqib et al. (20II), clas action research is a study which is held by the teacher by reflecting themselves to the purpose of repairing the performance so the result of the study of the student will be increasing as well. Revers to Arikunto (2012), there is four stages which are passed by (I) planning, (2) implementation (3) observation and (4) reflection.

The objective of the study: the factors of the teacher, students, and score.

The Data of the study is the qualitative and quantitative data. The quantitative data is the result of the teacher's learning process and the activities of the student's observation. Quantitative data is the score of the student's assignment which is held in the end of the learning process every meeting.

The successful indicators are the points follow: (a) the success of the activity of the teacher just if the activity of the teacher achieves 37-44. It means very good. (b) the success of the classical students in this learning process method by achieving the number of $\geq 63 \%$ according to the student's active interpretation. (c) the completeness of the student's score in the activity of learning process by achieving the number of $\geq 70 \%$, meanwhile for the completeness of the classical aspect, it has to achieve the number of $\geq 70$ from $80 \%$ of all the students.

\section{Results and Discussions}

According to the observation on cycle I and cycle II on the activity of the teacher, there is an increase of the effectiveness of the performance by the teacher while they were teaching. It can be seen in the cycle I, the first attendance of the meeting got the number of score 32 with predicate well done and the second attendance got the number of score 33 with predicate same as the first one. In the cycle II, the first attendance of the meeting got the number of score 37 with predicate very good and the second attendance got the number of score 44 with predicate same as the first one.

According to the result of the teacher's activity observation shows that the activity of the teacher has been increasing very well on each meeting, so it is affected to the increase the quality of the learning process as well. As the manager of the learning process, a teacher should determine which the method of the learning process that will be adopted effectually in order to make the process of the study will be going very well. In the application of the learning process combination of Cooperative Integrated Reading and Composition (CIRC), Team Assisted Individualization (TAI) and Numbered Head Together (NHT), besides of increasing the number of scores of the student, the teacher should be someone who has to develop the activity of the student as a whole nor in the group in the learning process. It is necessary to be done so the teacher has to create a fun learning atmosphere for the student. A good learning process will be so much helping the teacher to increase the activity and the score as the result of the learning process because the success of the teacher in the learning process itself supports the success of the student as well.

This is very appropriate with the opinion of Trianto (20II) which is mentioned that a good learning skill of the teacher is a prerequisite to the good learning activity of the student. One of the good learning activity characteristics to the student is when the student accepting and understanding the material of the study very well so the indicator and the purpose of the study can be reached as supposed to be.

A competence teacher will be increasing the possibilities of his/her learning process successful. According to Sudjana, the success of the students 
with their learning activity so much depends on the professionalism of the teacher. A professional teacher is a teacher who has the component of its subjects, well command about the materials that will be used on the learning process and choose the right method of the learning activity that will be adapted in order to reach the purpose of the study as well. Besides that, a teacher should be the person who has the main control of making a good atmosphere in the learning process because it had an effect on the success of the student itself. A conducive atmosphere of the learning process, a critical discussion of the class, a good feedback and well activity of the students will be so much giving the positive energy to the learning process so the purpose of the study can succeed very well, the success of the learning process to the student will increasing (Susanto, 2013).

On the student activity cycle I, the first meeting got the number of $21 \%$ of the student activity concentration. It means the student has been being active enough to the discussion; and on the second meeting, the percentage of the student activity concentration increasing to the number of $46 \%$. Both results show the predicate "Active Enough". On the student activity cycle II, the first meeting of the discussion got the number of $65 \%$ on the activity concentration. And it raised very well in the second meeting of the discussion by increasing the number of percentages to the $75 \%$ on the activity concentration. Both of the result on the cycle II shows the predicate "Active".

The increasing of the student activity by combining the method of Cooperative Integrated Reading and Composition (CIRC), Team Assisted Individualization (TAI) and Numbered Head Together (NHT) on the learning process affected to the desire and joyful feelings of the study because the student can learn and solve the problem together so they could help each other in the discussion. As what mentioned by Makawimbang (2009) the characteristic of the elementary school student should be I) enjoy playing activities, 2) enjoy exploring the environment, 3) enjoy working in groups, and 4) enjoy doing linear activities.

Therefore, a teacher should give an active, effective and fun to learn activities to the student by creating a good atmosphere and great combination method of Cooperative Integrated Reading and Composition (CIRC), Team Assisted Individualization (TAI) and Numbered Head Together (NHT).
The completeness percentage of the resulting study can be concluded by the achievement of the classical completeness aspect on the first meeting of the cycle I which showed the number of $27 \%$ where there are IO students complete the parameter. And then on the second meeting of the cycle II, there are 30 students that completed the parameter so the percentage has been increasing by the number of $81 \%$. On the first meeting of cycle II, there are 29 students has been completed the parameter so the percentage of the classical completeness shows the number of $78 \%$. And on the second meeting of cycle II, the percentage has been increasing by the number of $92 \%$ with the number of students is 34 . It shows the student activity at each meeting is very well increased.

The increasing of the student activity progress shows that the student learns and understand the materials very well. It is appropriate with the opinion of Hamalik (2013), the regulation of someone's behavior is being one of the proofs of that someone has been learning very well. From the notion of knowledge to well known and do not understand to understand.

The increasing of the result of the study has been affected by the accuracy of the teacher in adopting the learning process method of Cooperative Integrated Reading and Composition (CIRC), Team Assisted Individualization (TAI) and Numbered Head Together (NHT). The CIRC method can grow the skill analysis of the student and motivate the spirit of the student to be more dynamic, optimal and effective. The TAI method teaches the student how to work in a team, so the weak student will be so much be helped. According to Trianto (2009), Numbered Heads Together (NHT) cooperative learning method can increase the performance of the student, deepening the comprehension, pleasing the student in the learning process, developing the positive energy, leadership and curiosity skills. As what mentioned on the benefits learning method of NHT to the student who has the low result of the study, it will be increasing the confidence of the student and elevating the score of the learning result. (Suminanto, 2012).

\section{Conclussion and Recomendations}

According to the discussion, the result of the study using the combination learning method Cooperative Integrated Reading and Composition (CIRC), Team Assisted Individualization (TAI) and 
Numbered Head Together (NHT) on the intensively reading materials in the fourth grades SDN Pengambangan 9 Banjarmasin Timur are as follows:

I. The teacher activity on the second meeting discussion of the cycle I got the score 33 which is good, and the second meeting of cycle II got the score 42 which is excellent.

2. The student activity of the learning process on the first meeting discussion cycle I classically $46 \%$ in the active category and on the second meeting discussion in cycle II increasing at the number of $75 \%$.

3. The student's result of the study got $81 \%$ percentage on the first meeting discussion cycle I then increased to the number of $92 \%$ on the second meeting in cycle II.

According to the conclusion, the writer recommends some suggestions as follows:

The writer recommends to the teacher to adopt the combination of Cooperative Integrated Reading and Composition (CIRC), Team Assisted Individualization (TAI) and Numbered Head Together (NHT) learning method.

The writer recommends to the headmaster to supports the teachers for adopting any innovative learning methods which will be applied to the learning process especially in the subject Bahasa Indonesia.

The writer recommends to the other researcher to make another deep research about using the combination of Cooperative Integrated Reading and Composition (CIRC), Team Assisted Individualization (TAI) and Numbered Head Together (NHT) learning method in the world education learning process based on this study.

\section{Acknowledgment}

No Aknowledgment

\section{References}

Aqib, $\mathrm{Z}$ et al. (2011). Penelitian Tindakan Kelas. Bandung: CV. Yrama.

Arikunto, S. (20I2). Prosedur Penelitian suatu Pendekatan Praktik. Jakarta: PT. Rineka Cipta.

Daryanto. (2010) Media Pembelajaran. Yogyakarta: Gava Media.

Depdiknas. (2006). Pengembangan Silabus dan RPP Sekolah Dasar I-VI. Jakarta: Departemen Pendidikan Nasional

Hamalik, O. (2013). Proses Belajar Mengajar. Jakarta: Sinar Grafika.

Makawimbang, J. (201 I). Supervisi dan Peningkatan Mutu Pendidikan. Bandung: Alfabeta.

Nurhadi., \& Agus. (2003). Pembelajaran Kontekstual dan Penerapannya dalam KBK. Malang: Universitas Negeri Malang.

Rusman. (2010). Model-Model Pembelajaran Mengembangkan Profesionalisme Guru. Jakarta: Rajawali Pres.

Susanto, A. (2013). Teori Belajar \& Pembelajaran di Sekolah Dasar. Jakarta: Kencana Prenada Media Group.

Saminanto. (2012). Penelitian Tindakan Kelas. Semarang: Rasail Media Group.

Sardiman. (20II). Interaksi dan motivasi Belajar Mengajar. Jakarta: Rajawali Press.

Suriansyah, A. (20II). Landasan Pendidikan. Banjarmsain: Comdes.

Suyitno, A. (2007). Pemilihan Model-Model Pembelajaran dan Penerapannya di Sekolah. Jakarta: Pendidikan Tenaga Teknis Keagamaan-Depag.

Tarigan, H.G. (2009). Pengajaran Kompetisi Bahasa. Bandung: Angkasa.

Trianto. (2009). Mendesaign Model Pembelajaran Inovativ dan Progresif. Surabaya: Kencana, Prenada Media Group.

Trianto. (20II). Model-Model Pembelajaran Terpadu Konsep, Strategi dan Implementasinya dalam Kurikulumm Tingkat Satuan Pendidikan (KTSP). Jakarta: Bumi Aksara. 
ISSN 2580-2135 